\title{
Upaya Meningkatkan Soft SkillsPreseptor Melalui Pemanfaatan Telekonferensi Video
}

\author{
Rosalinna, ${ }^{1}$ Nanan Sekarwana, ${ }^{2}$ Farid Husin, ${ }^{3}$ Johanes C. Mose, ${ }^{4}$ Dany Hilmanto, ${ }^{5}$ Juntika Nurihsan ${ }^{6}$ \\ ${ }^{1}$ Mahasiswa Program Studi Magister Kebidanan, Fakultas Kedokteran, Universitas Padjajaran, \\ 2,5 Departemen Ilmu Kesehatan Anak Fakultas Kedokteran Universitas Padjajaran \\ ${ }^{3}$ Departemen Epidemiologi dan Biostatistika Fakultas Kedokteran Universitas Padjadjaran \\ ${ }^{4}$ Departemen Obstetri dan Ginekologi Fakultas Kedokteran Universitas Padjajaran \\ ${ }^{6}$ Program Studi Psikologi Pasca Sarjana Universitas Pendidikan Indonesia
}

\begin{abstract}
Abstrak
Kualitas soft skills preseptor memengaruhi kualitas lulusan bidan.Apabila soft skills preseptor dalam membimbing para bidan rendah, maka kualitas lulusannya pun rendah. Faktor yang mempengaruhi soft skills preseptor antara lain adalah beban kerja preseptor di rumah sakit yang tinggi. Penelitian ini bertujuan menganalisis pengaruh telekonferensi video terhadap peningkatan softskills preseptor. Adapun yang termasuk soft skills meliputi motivasi, disiplin, tanggung jawab, komunikasi dan kerja sama. Populasi dalam penelitian adalah preseptor dengan sampel terdiri dari 10 orang kelompok kontrol dan 10 orang pada kelompok perlakuan.Metode yang digunakan adalah metode kuasi eksperimen dengan rancangan nonequivalent pre-postwithcontrolgroup.Peneliti memasang alat telekonferensi video jenis Broadband Wireless Access (BWA) pada kelompok perlakuan. Sedangkan kelompok kontrol menjalankan bimbingan konvensional, yaitu tanpa menggunakan telekonferensi video.Adapun instrumen pengumpulan data menggunakan kuesioner dan lembar observasi.Analisis data soft skills kelompok penelitian menggunakan uji t tidak berpasangan atau uji Mann-Whitney sebagai uji alternatif.Untuk melihat besarnya pengaruh perlakuan terhadap peningkatan soft skills preseptor menggunakan regresi linear.Hasil penelitian menunjukkan bahwa telekonferensi video pada pembelajaran praktik klinik kebidanan berpengaruh besar terhadap soft skills preseptor.Persentase peningkatan soft skills preceptor dengan nilai rerata soft skillskelompok perlakuan yaitu 21,9\% lebih tinggi bila dibandingkan dengan kelompok kontrol yang hanya 7,4\%. Soft Skills preseptor Kelompok Perlakuan terbukti meningkat hingga 93,5\% dengan nilai $p=0,000$. Soft skills preseptor kelompok perlakuan menjadi lebih baik apabila dibandingkan dengan kelompok kontrol yang tanpa menggunakan telekonferensi video.Simpulan penelitian ini adalah telekonferensi video dalam pembelajaran praktik klinik kebidanan berpengaruh terhadap peningkatan soft skills preseptor.
\end{abstract}

Kata Kunci: Kebidanan, pembelajaran, praktik klinik, preseptor, soft skills, telekonferensi video 


\title{
The Effort to Improve the Preceptor's Soft Skills Through Video Teleconference Application
}

\begin{abstract}
The low soft skills preceptor in guiding caused by a high workload and it resulted in poor quality of graduates midwife. The purpose of this study was to analyze the influence of video teleconferencing to increase precept of soft skills which include motivation, discipline, responsibility, communication and cooperation. This research used a quasi-experimental design with pre-post nonequivalent control group. The research population is precept with a sample consisting of 10 control group and 10 people in the treatment group. Instrument data collection uses questionnaires and observation sheets. Soft skills of data analysis research groups using unpaired $t$ test or Mann-Whitney test as an alternative test. To see the effect of the treatment of soft skills enhancement precept of using linear regression. The results showed that there are differences in the percentage of soft skills precept increase to an average value of soft skills treatment group is $21.9 \%$ higher when compared with the control group $7.4 \%$. The amount of influence on learning video teleconferencing clinical practice midwifery to the increase in the amount of soft skills precept of $93.5 \%$ (adjusted R2 $=0.935$ and $p=0.000$ ) can increase the precept of the better soft skills when compared to learning without the use of video teleconferencing. The conclusions of this study are video teleconferencing in clinical midwifery practice learning soft skills affect the increase in precept.
\end{abstract}

Keywords:Midwifery, teaching, clinical practice, precept, softskill, video teleconference

\section{Pendahuluan}

Pendidikan kebidanan di Indonesia masih memiliki beberapa masalah.Sebagian besar masalah tersebut muncul selama pembelajaran praktik klinik kebidanan.Dalam tiga tahun terakhir, kompetensi bidan di Indonesia mengalami penurunan. Hasil uji kompetensi bidan yang dilaksanakan pada tahun 2013 dan diikuti oleh 106 sekolah kebidanan di Indonesia menunjukkan bahwa hampir sebagian besar atau $46,5 \%$ peserta uji kompetensi dinyatakan tidak lulus dan harus mengikuti remedial dengan batas kelulusan 40,14 ${ }^{1}$. Survei Kemenkes RI 20112012 juga menyatakan, hanya $15 \%$ pembelajaran praktik klinik tergolong kategori baik. Sedangkan sisanya, yakni $75 \%$ berada pada kategori perlu ditingkatkan. ${ }^{2}$

Menurut Tanriverdi dan Katar, salah satu permasalahan yang terjadi selama pembelajaran praktik klinik adalah sebagian besar atau 94,1\% mahasiswa tidak ditemani oleh staf pengajar (preseptor dan dosen pembimbing). ${ }^{3}$ Tim Pengembangan Sistem Pembelajaran Praktik Klinik Kebidanan Universitas Padjajaran Bandung telah mengadakan studi pendahuluan di enam rumah sakit di Jawa Barat. Studi itu mengungkapkan masalah-masalah yang muncul selama kegiatan praktik klinik menurut persepsi mahasiswa. Menurut hasil studi tersebut, sebanyak $15,3 \%$ responden menyatakan preseptor sibuk dengan pasien dan $11,3 \%$ menyatakan preseptor sibuk dengan tugas lain.
Sebanyak $18 \%$ responden juga menyatakan preseptor jarang membimbing mahasiswa.Selain itu, $12 \%$ responden menyatakan preseptor memiliki sikap tidak kooperatif, tidak bersahabat dan tidak mau membimbing mahasiswa.Fakta di lapangan menunjukkan kurangnya keterampilan interpresonal preseptor seperti hubungan tidak harmonis dengan mahasiswa sesama preseptor dengan staf rumah sakit. Ini tentunya akanmemberi dampak terhadap kinerja preseptor dalam pembelajaran praktik.

Munculnya permasalahan di atas antara lain disebabkan beban kerja yang tinggi telah menyebabkan soft skills preseptor dalam memberi bimbingan terhadap mahasiswa kebidanan rendah. Jam kerja preseptor di rumah sakit atau pun tempat praktik tergolong padat. Selain harus melayani pasien dengan baik, preseptor juga harus menjalankan tugas sebagai pembimbing mahasiswa kebidanan.Akibatnya, durasi bimbingan di antara jadwal kerja relatif terlampau singkat dan tidak berlangsung efektif.

Salah satu tugas preseptor, selain sebagai edukator adalah juga sebagai role model bagi mahasiswa kebidanan.Burns dkk menyatakan bahwa preseptor yang efektif adalah preseptor yang memiliki sikap positif dan efektif dalam menciptakan lingkungan yang mendukung pembelajaranpraktik. ${ }^{4}$ Madhavanprabhakaran dkk menyatakan sikap profesional merupakan karakteristik utama seorang preseptor yang diinginkan mahasiswa. ${ }^{5}$ 
Pendidikan tinggi yang tergolong baik, menurut Chickering dan Gamson (1987) seperti yang dikutip oleh Chen, Guidry dan Lambert (2009), pendidikan tinggi yang mendorong terjadinya interaksi mahasiswa dan institusi, kerjasamaantar mahasiswa, belajar aktif, mendorong adanya umpan balik (feedback), memiliki ekspektasi tinggi, menghargai perbedaan talenta dan cara belajar. ${ }^{6}$ Penelitian ini bertujuan untuk menganalisis pengaruh telekonferensi video terhadap peningkatan softskills preseptor. Adapun yang termasuk soft skills meliputi motivasi, disiplin, tanggung jawab, komunikasi dan kerja sama.

\section{Metode}

Penelitian ini menggunakan metode kuantitatif dengan rancangan penelitian ekperimen semu non-equivalent with control group design pre-test post-test terhadap 10 orang preseptor elompok kontrol dan 10 orang pada kelompok perlakuan.Analisis data menggunakan uji t tidak berpasangan melihat perbandingan soft skills preseptor dan regresi linear untuk melihat besarnya pengaruh perlakuan (telekonferensi video) terhadap peningkatan soft skills preseptor.

Objek penelitiannya adalah preseptor yang bertugas di ruang bersalin RSUD Majalaya dan RSUD Soreang.Sampel penelitian adalah seluruh preseptor yang bertugas membimbing mahasiswa selama PKK berlangsung dari September hingga Desember 2015.Jumlah preseptor yang sesuai dengan kriteria inklusi berjumlah 10 orang di setiap lokasi penelitian.

Pada Kelompok Kontrol, bimbingan yang dijalankan masih secara konvensional dan tidak diberi alat bantu apa pun. sedangkan pada Kelompok Perlakuan, selama proses bimbingan dipantau alat telekonferensi video yang tersambung dengan para dosen dari institusi yang bersangkutan. Dengan demikian, bimbingan berlangsung secara interaktif.

Analisis data menggunakan uji $\mathrm{t}$ tidak berpasangan untuk melihat perbandingan soft skills preseptor dan multivariate untuk melihat besarnya pengaruh telekonferensi video terhadap peningkatan soft skillspreseptor.

\section{Hasil}

Alat telekonferensi video yang digunakan dalam penelitian ini adalah jenis Broadband Wireless Access (BWA).Alat ini merupakan teknologi lokal berkualitas tinggi.Data audio visual mampu diakses dalam jarak 50 kilometer (31 mil), tanpa menggunakan kabel dan sambungan internet, tidak bergantung pada kondisi wilayah, sehingga bisa digunakan baik di pesisir pantai, dataran rendah maupun dataran tinggi. Teknologi BWA memiliki tipologi pengiriman data dari satu titik ke banyak titik (point to multi point).

Karakteristik kedua kelompok sebagian besar memiliki usia antara 25-30 tahun (75\%) dengan lama kerja 6-10 tahun (40\%). Lebih jelas bisa dilihat pada tabel

Tabel 1. Karakteristik Subjek Penelitian Pada Kedua Kelompok Penelitian

\begin{tabular}{llll}
\hline Karakteristik & Kelompok & \\
\cline { 2 - 3 } & $\begin{array}{c}\text { Perlakuan } \\
(\mathbf{n}=\mathbf{1 0})\end{array}$ & $\begin{array}{c}\text { Kontrol } \\
(\mathbf{n}=\mathbf{1 0})\end{array}$ & Nilai $\boldsymbol{p}$ \\
\hline Usia & $9(90 \%)$ & $6(60 \%)$ & $\left.0,111^{*}\right)$ \\
$\quad 25-30$ & $1(10 \%)$ & $2(20 \%)$ & \\
$\quad 31-35$ & 0 & $2(20 \%)$ & \\
$\quad>35$ & & & \\
Lama Kerja & $4(40 \%)$ & $3(30 \%)$ & $\left.0,277^{*}\right)$ \\
$\quad<5$ & $5(50 \%)$ & $3(30 \%)$ & \\
$\quad 6-10$ & $1(10 \%)$ & $4(40 \%)$ & \\
$>10$ & & & \\
Nilai pre-test soft skill Preseptor & & & \\
Total Soft Skills & $73,9(1,6)$ & $71,2(3,6)$ & $\left.0,048^{* *}\right)$ \\
$\quad$ Rerata (SD) & 73,3 & 71,4 & \\
$\quad$ Median & $72,1-77,1$ & $64,5-76$ & \\
$\quad$ Rentang & &
\end{tabular}

Keterangan.: ${ }^{*}$ Uji Mann-Whitney; $p<0,05 ;{ }^{* *}$ ) Uji t tidak berpasangan 
Dari segi karakteristik subjek, penelitian ini menunjukan bahwa faktor usia dan lama kerja penelitian.Peningkatan nilai rerata soft
tidak mempengaruhi peningkatan soft kedua kelompok disajikan pada tabel 1.

skillspreseptor pada kedua kelompok

Tabel 2 Perbedaan Peningkatan Soft Skills Preseptor pada Kedua Kelompok Penelitian

\begin{tabular}{|c|c|c|c|c|c|}
\hline \multirow{3}{*}{ Variabel SoftSkills } & \multicolumn{4}{|c|}{ Kelompok } & \multirow{3}{*}{ Nilai $p^{* * *}$} \\
\hline & \multicolumn{2}{|c|}{ Perlakuan $(n=10)$} & \multicolumn{2}{|c|}{ Kontrol $(n=10)$} & \\
\hline & Pre & Post & Pre & Post & \\
\hline \multicolumn{6}{|l|}{ Motivasi: } \\
\hline Rerata (SD) & $64,4(4,6)$ & $85,4(4,0)$ & $61,2(10,2)$ & $73,6(6,3)$ & \\
\hline Median & 65 & 87 & 61 & 76 & \\
\hline Rentang & $54-70$ & $80-90$ & $44-74$ & $58-80$ & \\
\hline Nilai $p_{\text {(beda berpasangan) }}$ & \multicolumn{2}{|c|}{$0,005^{*}$} & \multicolumn{2}{|c|}{$0,005^{*}$} & \\
\hline Selisih $(\Delta)=$ post-pre & \multicolumn{2}{|c|}{$21(61)$} & \multirow{2}{*}{\multicolumn{2}{|c|}{$12.4(6.2)$}} & \\
\hline Rerata (SD) & \multirow{2}{*}{\multicolumn{2}{|c|}{$\begin{array}{c}21(6,1) \\
23\end{array}$}} & & & \\
\hline Median & & & \multirow{2}{*}{\multicolumn{2}{|c|}{$\begin{array}{c}13 \\
4-24\end{array}$}} & 0,006 \\
\hline Rentang & \multicolumn{2}{|c|}{$12-28$} & & & \\
\hline$\%$ Peningkatan rerata & \multicolumn{2}{|c|}{32,6} & \multicolumn{2}{|c|}{20,3} & \\
\hline \multicolumn{6}{|l|}{ Disiplin: } \\
\hline Rerata (SD) & $70,6(7,8)$ & $92,4(2,1)$ & $67,9(4,4)$ & $78,7(5,1)$ & \\
\hline Median & 68,3 & 93,3 & 69 & 80 & \\
\hline Rentang & $62,2-90$ & $88,3-95$ & $56,7-73,3$ & $66,7-85$ & \\
\hline $\begin{array}{l}\text { Nilai } p_{(\text {beda berpasangan) }} \\
\text { Selisih }(\Delta)=\text { post-pre }\end{array}$ & \multicolumn{2}{|c|}{$0,005^{*}$} & & & \\
\hline Rerata (SD) & 21 , & & & & \\
\hline Median & & & & & 0,004 \\
\hline Rentang & & & $(-3$, & & \\
\hline$\%$ Peningkatan rerata & & & & & \\
\hline Tanggung Jawab: & & & & & \\
\hline Rerata (SD) & $76,8(2,3)$ & $92,1(1,7)$ & $72,1(2,2)$ & $75,8(2,1)$ & \\
\hline Median & 76,9 & 92,5 & 71,5 & 75,5 & \\
\hline Rentang & $73,4-80$ & $90-95$ & $70-76,3$ & $72,5-80$ & \\
\hline Nilai $p_{\text {(beda berpasangan) }}$ & & & & & \\
\hline Selisih $(\Delta)=$ post-pre & & & & & \\
\hline Rerata (SD) & & & & & \\
\hline Median & & & & & 0,000 \\
\hline Rentang & & & & & \\
\hline$\%$ Peningkatan rerata & & & & & \\
\hline Komunikasi: & & & & & \\
\hline Rerata (SD) & $82,3(2,4)$ & $92,6(4,1)$ & $81,3(2,7)$ & $82,2(2,7)$ & \\
\hline Median & 81,7 & 90,7 & 81,3 & 81,6 & \\
\hline Rentang & $80-86,3$ & $88,8-101,3$ & $75,8-86,3$ & $79,4-87$ & \\
\hline Nilai $p_{\text {(beda berpasangan) }}$ & & & & & \\
\hline Selisih $(\Delta)=$ post-pre & & & & & \\
\hline Rerata (SD) & 10, & & & & \\
\hline Median & & & & & 0,000 \\
\hline Rentang & & & & & \\
\hline$\%$ Peningkatan rerata & & & & & \\
\hline Kerja sama: & & & & & \\
\hline Rerata (SD) & $75,3(5,3)$ & $88,3(2,9)$ & $73,6(3,9)$ & $72,5(3,9)$ & \\
\hline Median & 75,5 & 88 & 74 & 73,5 & \\
\hline Rentang & $64-82$ & $85,3-94$ & $68-80$ & $67-78$ & \\
\hline Nilai $p_{\text {(beda berpasangan) }}$ & & & & & \\
\hline Selisih $(\Delta)=$ post-pre & & & & & \\
\hline Rerata (SD) & 13 , & & $(-1$, & ,1) & \\
\hline Median & & & & & 0,000 \\
\hline Rentang & & & & & \\
\hline$\%$ Peningkatan rerata & & & & & \\
\hline Total Soft Skills & & & & & \\
\hline Rerata (SD) & $73,8(1,6)$ & $90,1(1,9)$ & $71,2(3,6)$ & $76,5(1,8)$ & \\
\hline Median & 73,3 & 90,0 & 71,4 & 76,3 & \\
\hline Rentang & $72,0-77,1$ & $87,0-94,7$ & $64,5-75,9$ & $73,4-79,3$ & \\
\hline Nilai $p_{\text {(beda berpasangan) }}$ & & & & & \\
\hline
\end{tabular}




\begin{tabular}{|c|c|c|c|}
\hline \multirow{2}{*}{\multicolumn{4}{|c|}{ Selisih $(\Delta)=$ post-pre }} \\
\hline & & & \\
\hline Rerata (SD) & $16,2(2,5)$ & $5,3(3,6)$ & 0000 \\
\hline Median & 16,2 & 4,3 & 0,000 \\
\hline Rentang & $12,8-20,7$ & $0,5-12,1$ & \\
\hline$\%$ Peningkatan rerata & 21,9 & 7,4 & \\
\hline
\end{tabular}

Pada tabel 2, kita bisa melihat peningkatan persentase nilai rerata kedua kelompok. Komunikasi memiliki nilai peningkatan tertinggi, yaitu $12,5 \%$, pada kelompok perlakuan. Sedangkan nilai peningkatan terendah ada pada motivasi, yaitu hanya $1,6 \%$. Variabel lainnya, yaitu kerjasama mengalami peningkatan nilai rerata $10,8 \%$. Sementara peningkatan tanggungjawab sebesar 3,9\% dan disiplin $1,9 \%$. Hasil pada ke dua kelompok penelitian, persentase peningkatan soft skills mencapai $2,96 \%$.

Sehubungan masih adanya ketidaksetaraan soft skillsawal pada kedua kelompok (tabel 1), maka peneliti melanjutkan analisis multivariat. Hal ini dilakukan untuk melihat seberapa besar pengaruh soft skillsawal dan perlakuan, yakni pemanfaatan telekonferensi video, terhadap peningkatan soft skills preseptor. Hasil analisisnya bisa dilihat pada tabel 3 .

Tabel 3.Pengaruh Telekonferensi Video Pada Pembelajaran Praktik Klinik terhadap Peningkatan Soft Skills Preseptor

\begin{tabular}{llccc}
\hline \multicolumn{1}{c}{ Langkah } & \multicolumn{1}{c}{ Variabel } & Koefisin $\boldsymbol{\beta}$ & SE ( $\boldsymbol{\beta})$ & Nilai $\boldsymbol{p}$ \\
\hline Langkah 1 & Nilai soft skills pre-test & 0,107 & 0,163 & 0,522 \\
& Telekonferensi video & 13,333 & 0,961 & 0,000 \\
& Konstan & 68,921 & & \\
& & & & 0,000 \\
Langkah 2 & Telekonferensi video & 13,614 & 0,846 & \\
& Konstan & 76,540 & & \\
\hline
\end{tabular}

Keterangan: Skor soft skillspost $=76,54+13,614 \mathrm{x}$ kelompok; $0=$ kelompok kontrol; $1=$ kelompok perlakuan

Tabel 3 menunjukkan hasil uji statistik regresi linear antara variabel bebas yaitu nilai soft skillspre dan perlakuan (pemanfaatan telekonferensi video) dengan variabel terikat yaitu nilai soft skillspost.Hasilnya adalah, sebesar 93,5\% variasi nilai soft skillspost dipengaruhi oleh Perlakuan (pemanfaatan telekonferensi video) dan 6,5\% dipengaruhi oleh faktor lain.

Mengingat pada tabel 2 sebelumnya terdapat perbedaan peningkatan signifikan dalam hal soft skills preseptor.Maka berdasarkan tabel 3, bisa disimpulkan bahwa telekonferensi video berpengaruh terhadap peningkatan soft skills preseptor dalam pembelajaran praktik klinik kebidanan.

Pemanfaatan alat BWA ini terbukti mampu mengatasi kendala waktu di lahan praktik. Preseptor memiliki jam kerja panjang dan padat, namun masih dapat memberikan bimbingan yang dibutuhkan bagi mahasiswa. Dan proses bimbingan preseptor bagi mahasiswa kebidanan berlangsung lebih efektif dan efisien. Dengan demikian, preseptor dapat menjalankan fungsinya sebagai edukator dan role model secara lebih baik.

\section{Pembahasan \\ Telekonferensi Meningkatkan Soft Skills Preseptor}

Banyak bukti yang menyatakan bahwa pemanfaatan teknologi secara efektif dapat menjadi sarana yang mendukung pembelajaran.Upaya pembelajaran praktik klinik perlu didorong ke arah pemanfaatan teknologi sebagai salah satu bentuk perbaikan kualitas pendidikan kebidanan di Indonesia.Pemanfaatan teknologi sebagai sarana pendukung pembelajaran dapat memperbaiki dan meningkatkan kualitas pendidikan ${ }^{7}$.Inovasi teknologi saat ini semakin pesat dan user friendly dalam memberikan kemudahan dalam aktivitas keseharian termasuk pendidikan dan kesehatan.

Dalam mengatur jam kerja preseptor yang padat, peneliti mencoba memanfaatkan keberadaan teknologi berupa video telekonferensi kemudian, menganalisis pengaruhnya terhadap pembelajaran praktik klinik terhadap peningkatan soft skills preseptor. Salah satu rekomendasi WHO mengenai peningkatan kualitas pendidikan kesehatan adalah melalui pemanfaatan teknologi. ${ }^{8}$ Video telekonferensi boleh dibilang salah satu bentuk 
pemanfaatan teknologi untuk melakukan pembelajaran jarak jauh.Dengan demikian,diharapkan keberadaan teknologi ini bisa memangkas jarak dan waktu yang selama ini menjadi kendala dalam pembelajaran klinik.

Soft skills sendirimerupakan sikap dan perilaku individu dalam interaksi sosial.Keterampilan ini memberikan dampak positif dalam perilaku individu. Keterampilan ini terbentuk dalam diri individu melalui proses belajar. Penerapan keterampilan ini dalam interaksi pun bergantung pada karakter tiap individu. ${ }^{9}$ Soft skills adalah kepribadian non teknis dan perilaku yang dibutuhkan dalam sebuah kesuksesan karir.Kualitas kepribadian ini memungkinkan setiap individu menggunakan kemampuan teknis dan pengetahuan yang dimiliki secara efektif. ${ }^{10}$

Menurut Bjorg, Arne, dan Gunnar (2013), soft skills preseptor dapat dibangun melalui proses bimbingan dan pemantauan yang berkesinambungan. Adanya hubungan yang dibentuk dari interaksi antar preseptor, dosen pembimbing, mahasiswa merupakan faktor penting dalam keberhasilan pembelajaran praktik klinik. ${ }^{11}$

Pengembangan soft skills di perguruan tinggi beberapa tahun belakangan menjadi perhatian para akademisi dalam bidang pendidikan.Hal tersebut bertujuan untuk memperbaiki kualitas lulusan. Pengembangan soft skills di perguruan tinggi, menurut Sailah dapat dilakukan dengan tiga cara, yaitu; )lecturerole model; 2) messageoftheweek; 3) hidden curriculum. ${ }^{12}$

Dalam penelitian ini, soft skills yang diteliti meliputi motivasi, disiplin, tanggung jawab, komunikasi dan kerjasama. Melalui penelitian ini, peneliti ingin mengetahui apakah teknologi mempengaruhisoft skills.Selain itu, apakah dengan adanya telekonferensi video soft skills preseptor meningkat atau justru menurun.

Studi literatur tersistematis juga dilakukan oleh Fatehi, Armfield, Dimitrijevic dan Gray (2014). Dengan menggunakan pencarian elektronik terhadap artikel terkait aplikasi telekonferensi video dari tahun 2002-2012 dan 505 artikel yang memenuhi kriteria inklusi, hasil studi ini menyimpulkan bahwa telekonferensi video paling banyak digunakan dalam dunia kesehatan untuk tujuan manajemen, diagnosis, konseling, monitoring dan skrening. ${ }^{13}$

Telekonferensi video dapat memberikan kesempatan melalui media audio visual untuk meningkatkan pencapaian hasil belajar melalui pembelajaran jarak jauh. Adanya dukungan visual dan mentoring secara berkesinambungan melalui telekonferensi media dapat memfasilitasi proses pembelajaran secara intelektual dan emosional, adanya interaksi, kerjasama, partisipasi secara nyata, dan dapat menghemat biaya yang dikeluarkan dalam bimbingan ke lahan praktik. Pemanfaatan teknologi telekonferensi video, menurut Newman et al. dalam dunia pendidikan dan kesehatan bertujuan membangun komunitas belajar dan interaksi diantara akademisi, peneliti dan paramedis dengan cara lebih mudah. ${ }^{14}$

Pemanfaatan telekonferensi video saat ini adalah melakukan pembelajaran jarak jauh atau e-learning. Beberapa alasan yang menjadi pertimbangan dalam pemanfaatan teknologi ini antara lain biaya perjalanan yang semakin mahal, kondisi finansial dan kurangnya sumber daya manusia. Beberapa tren pemanfaatan teknologi ini dalam pendidikan medis antara lain melakukan mentoring, membimbing mahasiswa selama praktik klinik dan melakukan konferensi medis. ${ }^{15}$

Pada daerah terpencil yang sulit dijangkau, teknologi ini berperan penting dalam memberikan dukungan dan layanan kesehatan serta pendidikan kesehatan. ${ }^{16}$ Dalam sebuah survei mengenai pemanfaatan telekonferensi video di Australia, Newman, Martin, McGarry, dan Cashin menyatakan bahwa telekonferensi video merupakan salah satu sarana pengembangan profesional komunitas bagi perawat.Dengan hadirnya telekonferensi video, komunikasi ini dapat melibatkan semua pihak terkait untuk melakukan pertukaran ilmu pengetahuan dan pengembangan keterampilan profesional atau softskills tidak dibatasi oleh permasalahan geografis baik di daerah perkotaan maupun di daerah terpencil. ${ }^{17}$

Blum, Kamciyan dan Dean (2012) menyimpulkan bahwa teknologi dapat membantu peran preseptor untuk mengatasi situasi sulit yang penuh dengan tekanan.Salah satu model teknologi yang dapat membantu peran preseptor, misalnya dalam penelitian mereka adalah podcast.Podcast adalah media digital yang mampu merekam aktivitas pembelajaran secara audio dan video. Penggunaan teknologi podcast antara lain sebagai sumberdaya pembelajaran yang bernilai untuk mengkaji, memperkuat dan menjelaskan kesulitan-kesulitan yang terjadi selama proses pembelajaran. ${ }^{18}$

Fidishun (2000), dalam Malinovski dkk (2015) menyatakan bahwa faktor-faktor yang dapat meningkatkan motivasi dalam 
pembelajaran seperti kepuasan bekerja dan kualitas hidup dapat didorong untuk menciptakan pembelajaran yang kolaboratif melalui telekonferensi video. ${ }^{19}$

Dalam konteks pembelajaran praktek klinik, telekonferensi video dalam pandangan Marrow dkk merupakan suatu upaya yang efektif dalam melakukan supervisi klinik.Supervisi klinik bukan hanya pada keterampilan klinik saja, terhadap sikap dan perilaku. Para preseptor mampu merefleksikan apa yang mereka lihat, mengembangkan kesadaran terhadap tindakan yang telah dilakukan dan mampu melihat dengan jelas isu-isu terkait pembelajaran praktik klinik. Lebih lanjut menurut Marrow dkk., dengan adanya dukungan teknologi ini mendorong preseptor untuk memahami tujuan dan hasil-hasil dari pembelajaran praktik klinik dan mengembangkan hubungan melalui peningkatan keterampilan komunikasinya. ${ }^{20}$

Telekonferensi video mampu mengatasi kendala jarak dan waktu, ada beberapa pertimbangan dalam pemanfaatan telekonferensi video perlu diperhatikan. Menurut Gilles (2008) menyatakan bahwa ada enam elemen yang menjadi pertimbangan dalam pemanfaatan

\section{Daftar Pustaka}

1. Kemenkes RI. Panitia Uji Kompetensi: Gambaran Pelaksanaan Uji Kompetensi TenagaKesehatan Periode I Tahun 2014 [Internet]. Panitia Uji Kompetensi. 2014.

2. Kemenkes RI. Survei Kualitas Pendidikan Keperawatan dan Kebidanan di Indonesia Tahun 2011-2012. Kementerian Kesehatan RI. Jakarta.2013

3. Katar Tanriverdi Gulbu, Tugba. Problems Experienced by Midwifery And Nursing Students in Turkey During Clinical Practice and Their Recommended Solutions to The Problems. International Journal of Caring Sciences. 2009. Vol. 2. 22-31

4. Catherine Burns, Michelle Beauchesne, Patricia RyanKrause, Kathleen Sawin. Mastering the Preceptor Role: Challenges of Clinical Teaching. Journal of Pediatric Health Care. 2006. Vol.20 No. 3. 172-183

5. Girja K Madhavanprabhakaran, Raghda K Shukri, Jahara Hayudini, Suresh K Narayanan. Undergraduate Nursing Students' Perception of Effective Clinical Instructor: Oman. International Journal of Nursing Science. 2013. Volume 3(2). 38-44

6. Pu-Shih Daniel Chen, Kevin R. Guidry, \& Amber D. Lambert. Engaging Online Learners: A Quantitative Study of Postsecondary Student Engagement in The Online Learning Environment. Annual Meeting of The American Educational Research Association; San Diego: University of North Texas; 2009.

7. Munir. Kurikulum Berbasis Teknologi Informasi dan Komunikasi (TIK): SPS Universitas Pendidikan Indonesia.

8. WHO. Midwifery Educator Core Competencies. 2013. Available from: telekonferensi video dalam proses pembelajaran. Elemen-elemen tersebut antara lain: 1) apa manfaat yang ditawarkan oleh pembelajaran dengan menggunakan telekonferensi video; 2) apakah stakeholder dalam proses pembelajaran terbiasa menggunakan teknologi; 3) bagaimana tingkat keterampilan penguasaan bahasa; 4) bagaimana tingkat penguasaan teknologi stakeholder dalam proses pembelajaran; dan 5) apa isi pembelajaran yang ditawarkan dengan menggunakan telekonferensi video. ${ }^{21}$

\section{Simpulan}

Telekonferensi video berpengaruh pada pembelajaran praktik klinik kebidanan terhadap peningkatan softskills dengan persentase peningkatan $93,5 \%$ bila dibandingkan dengan pembelajaran praktik klinik kebidanan tanpa menggunakan telekonferensi video. Pengaruh telekonferensi video pada variabel komunikasi memiliki peningkatan tertinggi dengan nilai rerata $12,5 \%$. Sedangkan peningkatan nilai rerata terendah adalah variabel motivasi dengan persentase peningkatan nilai rerata $1,6 \%$.

9. Saeful Zaman, Tim Gibasa Consultant. Revolusi Mental Dalam Praktek Soft Skills. Bandung: Media Perubahan; 2015.

10. Peggy Klaus. The Hard Truth About Soft Skills: Workplace Lessons Smart People, Wish They'd Learned Sooner. New York: HarperCollins; 2007

11. Dale Bjorg, Leland Arne, Gunnar DJ. What Factors Facilitate Good Learning Experiences in Clinical Studies in Nursing: Bachelor Students Perceptions. ISRN Nursing. 2013.

12. Illah Sailah. Pengembangan Soft Skills Di Perguruan Tinggi. Jakarta: Direktorat Jenderal Perguruan Tinggi. 2008.

13. Farhad Fatehi, Nigel R Armfield, Mila Dimitrijevic, Leonard C Gray. Clinical Application of Videoconferencing: A Scoping Review of The Literature for Period 2002-2012. Journal of Telemedicine and Telecare. 2014. Vol. 20(7). 377-383

14. C Newman, E. Martin, DE. McGarry, \& A. Cashin. Survey of a Videoconference Community of Professional Development for Rural and Urban. The International Electronic Journal of Rural and Remote Health Research, Education, Practice and Policy. 2009. 9. 1-8

15. Lamba Pankaj. Teleconferencing in Medical Education: A Useful Tool. Australasian Medical Journal. 2011. Vol. 4 (8). 442-447

16. Bruno Monteiro Tavares. Pereira, Thiago Rodrigues Araujo Calderan, Marcos Tadeu Nolasco Da Silva, Antonio Carlos Marttos Jr \& Gustavo Pereira Fraga. Initial Experience at University Teaching Hospital From Using Telemedicine to Promote Education Through Video Conferencing. Sao Paulo Medical Journal. 2012. Vol. 130 (1). 32-36 
17. C Newman, E. Martin, DE. McGarry, \& A. Cashin. Survey of a Videoconference Community of Professional Development for Rural and Urban. The International Electronic Journal of RUral and Remote Health Research, Education, Practice and Policy. 2009. 9. $1-8$

18. Cynthia A. Blum, Jeanette Kamciyan, Amy Dean. Stakeholder Focus Groups to Inform a TechnologyBased Strategy of Preceptor Support. Nursing Research and Practice. 2012. Vol. 2012. 1-7

19. Tony Malinovski, Tatjana Vasileva-Stojanovska, Dobri Jovevski. Adult Students' Perception in Distance Education Learning Environments Based on a Videoconferencing Platform - QoE Analysis. Journal of Information Technology Education: Research. 2015. Vol. 14.

20. Carole E. Marrow, Hamer, Dorothy., Kenrick , Catherine. Clinical Supervision Using VideoConference Technology : A Reflective Account. Journal of Nursing Management. 2002. 10. 275-282

21. The DLF Teaching Development Team. Teaching Via Video Vonference. Australia: Deakin University, 2013. Avalaible from www.deakin.edu.au/learningfutures 
Rosalinna :Upaya Meningkatkan Soft SkillsPreseptor Melalui Pemanfaatan Telekonferensi Video 
Rosalinna :Upaya Meningkatkan Soft SkillsPreseptor Melalui Pemanfaatan Telekonferensi Video 